\title{
A STUDY OF CATALYSTS AND MECHANISMS IN SYNTHESIS REACTIONS
}

\author{
Progress Report
}

January 1994 - December 1994

J. H. Lunsford

Department of Chemistry

Texas A\&M University

College Station, Texas 77843

August 1994

\section{PREPARED FOR THE U.S. DEPARTMENT OF ENERGY UNDER GRANT NUMBER DE-FG03-94ER14417}

\section{DISCLAIMER}

This report was prepared as an account of work sponsored by an agency of the United States Government. Neither the United States Government nor any agency thereof, nor any of their employees, makes any warranty, express or implied, or assumes any legal liability or responsibility for the accuracy, completeness, or usefulness of any information, apparatus, product, or process disclosed, or represents that its use would not infringe privately owned rights. Reference herein to any specific commercial product, process, or service by trade name, trademark, manufacturer, or otherwise does not necessarily constitute or imply its endorsement, recommendation, or favoring by the United States Government or any agency thereof. The views and opinions of authors expressed herein do not necessarily state or reflect those of the United States Government or any agency thereof.

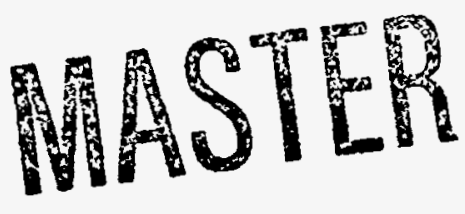




\section{DISCLAIMER}

Portions of this document may be illegible in electronic image products. Images are produced from the best available original document. 


\section{9}

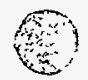

\section{INTRODUCTION}

Surface-generated gas-phase radicals, which are the subject of this study, may function as important.intermediates in several important partial and complete oxidation reactions. Two examples are the role of $\mathrm{CH}_{3} \cdot$ radicals in the oxidative coupling of $\mathrm{CH}_{4}$ and the role of $\mathrm{OH}$. radicals in the catalytic combustion of $\mathrm{CH}_{4}$. Although the gas phase chemistry of simple hydrocarbon radicals is reasonably well understood, very little is known about the reactions that occur between these radicals and metal oxide surfaces. Moreover, the formation of hydroxyl radicals over oxides is a largely unexplored area of catalysis. Recent work in our laboratory has been devoted to the reactions of methyl radicals with reactive metal oxides, and the production of hydroxyl radicals under rate limiting conditions.

\section{REACTIONS OF $\mathrm{CH}_{3} \cdot$ RADICALS WITH METAL OXIDES}

Metal oxides exhibit very large differences in $C_{2}$ selectivities (ethane and ethylene) during the oxidative coupling of $\mathrm{CH}_{4}$. These differences, may be attributed, in part, to secondary reactions that occur with the surface before coupling of $\mathrm{CH}_{3} \cdot$ radicals occurs. Radicals will collide with the surface $c a .10^{5}$ times before coupling with another radical; therefore, if the reactive sticking coefficient is of this order of magnitude, the $C_{2}$ selectivity will be small. In an earlier study (1) we reported on the differences in sticking coefficients for several selective and nonselective coupling catalysts. Although this pioneering work demonstrated that the differences in sticking coefficients indeed were very large between types of oxides, the $\mathrm{CH}_{3}$. radicals were formed under catalytic conditions, and other gases, including unreacted $\mathrm{CH}_{4}$ and $\mathrm{O}_{2}$ as well as the products $\mathrm{H}_{2} \mathrm{O}$ and $\mathrm{O}_{2}$, were present in the system. In order to more clearly delineate the factors that affect sticking coefficients, the experiments, using our matrix isolation electron spin resonance (MIESR) system, have been refined by generating $\mathrm{CH}_{3} \cdot$ radicals from the thermal decomposition of azomethane, $\mathrm{CH}_{3} \mathrm{~N}=\mathrm{NCH}_{3}$. This is a relatively clean reaction which yields mainly $\mathrm{CH}_{3} \cdot$ radicals and $\mathrm{N}_{2}$. When 
desirable, $\mathrm{O}_{2}$ or $\mathrm{CO}_{2}$ could be added separately. Furthermore, the reactions were carried out in a Knudsen cell, which served as a well mixed reactor.

The results obtained using the new system are summarized in Fig. 1. In the absence of added $\mathrm{O}_{2}$, the selective catalysts, such as $\mathrm{Li} / \mathrm{MgO}, \mathrm{La}_{2} \mathrm{O}_{3}$ and $\mathrm{Sr} / \mathrm{La}_{2} \mathrm{O}_{3}$ have reactive sticking coefficients that are approximately two orders of magnitude less than those of the nonselective catalysts, $\mathrm{CeO}_{2}$ and $\mathrm{ZnO}$. The addition of even $0.1 \mathrm{mTorr}$ of $\mathrm{O}_{2}$ produced a large increase in the reactive sticking

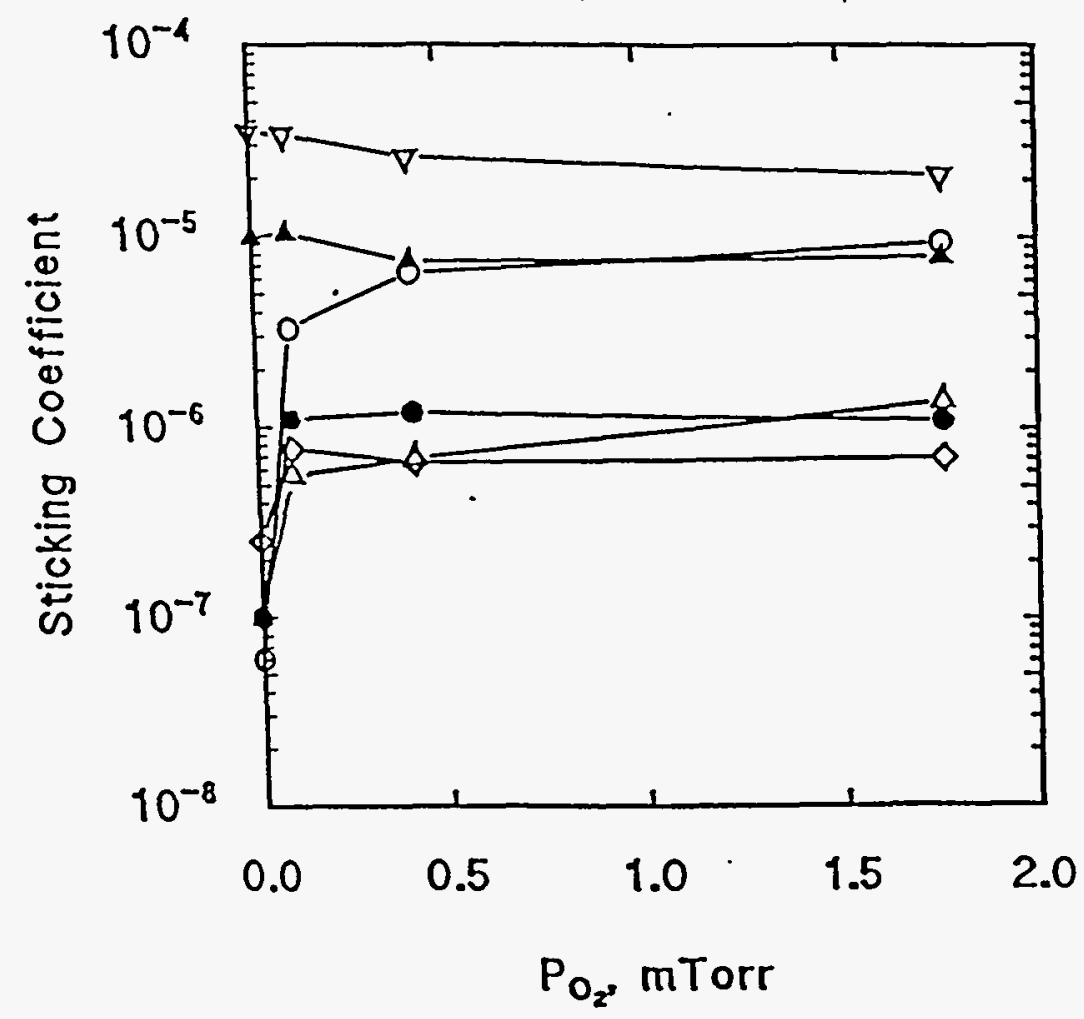

Fig. 1. Sticking coefficients of $\mathrm{CH}_{3} \cdot$ radicals on metal oxides with respect to the partial pressure of $\mathrm{O}_{2}$. All metal oxides were pretreated at 700 ${ }^{\circ} \mathrm{C}$ and run at $650^{\circ} \mathrm{C}$, except where specified. $\mathrm{O}, \mathrm{La}_{2} \mathrm{O}_{3}$, pretreated at $900{ }^{\circ} \mathrm{C} ; \bullet, \mathrm{La}_{2} \mathrm{O}_{3} ; \nabla, \mathrm{ZnO}$, run at $500^{\circ} \mathrm{C} ; \Delta, \mathrm{CeO}_{2} ; \diamond, 4.1 \mathrm{wt} \%$ $\mathrm{Li} / \mathrm{MgO} ; \Delta, 1 \mathrm{wt} \% \mathrm{Sr} / \mathrm{La}_{2} \mathrm{O}_{3}$.

coefficient, but, in general, the value remained $<1 \times 10^{-6}$. The exception was $\mathrm{La}_{2} \mathrm{O}_{3}$ that had been degassed at $900^{\circ} \mathrm{C}$. Nitrous oxide, however, had almost no measurable effect on 
the sticking coefficients, which is in agreement with the larger $C_{2}$ selectivities than may be attained with $\mathrm{N}_{2} \mathrm{O}$ as the oxidant (2). The presence of $\mathrm{CO}_{2}$ had a negative effect on the sticking coefficient on $\mathrm{La}_{2} \mathrm{O}_{3}$ and $\mathrm{Li} / \mathrm{MgO}$, but not on $\mathrm{Sr} / \mathrm{La}_{2} \mathrm{O}_{3}$. The effect of $\mathrm{CO}_{2}$ on $\mathrm{Li} / \mathrm{MgO}$ is consistent with the observation that $\mathrm{CO}_{2}$ improves the selectivity of this material (3). The presence of $\mathrm{CH}_{4}$ had no measurable effect on the sticking coefficient of $\mathrm{CH}_{3}$. radicals on $\mathrm{Sr} / \mathrm{La}_{2} \mathrm{O}_{3}$.

Although high surface area, porous materials are generally poor oxidative coupling catalysts, the reason for the loss in selectivity is not well understood. One might expect that the cavities or pores would give rise to a cage effect which would promote radical coupling. On the other hand, the number of collisions with the surface is proportional to the surface area. The percentage of radicals that reacted with $100 \mathrm{mg}$ of catalyst increased from $36 \%$ in Cab-O-Sil Silica $\left(\mathrm{SA}=270 \mathrm{~m}^{2} / \mathrm{g}\right)$ to $90 \%$ in a H-Y zeolite $\left(\mathrm{SA} \propto 900 \mathrm{~m}^{2} / \mathrm{g}\right)$, thus the percentage of $\mathrm{CH}_{3} \cdot$ radicals that react appears to be proportional to the surface area. But when the results for other samples are compared, it appears that factors in addition to surface area affect the sticking coefficient. For example, only $74 \%$ of the radicals reacted in a nay zeolite which had a surface area comparable to that of the H-Y zeolite. The origin of this latter effect, and the nature of the reactions in these high surface area materials is currently being explored. By using a mass spectrometer with a variable ionizing voltage, it is possible to detect only $\mathrm{CH}_{3}$. radicals or mainly stable molecules. $\left(\mathrm{CH}_{3} \cdot\right.$ radicals have an ionization potential of $9.8 \mathrm{eV}$ compared to a value of 12.8 for $\mathrm{CH}_{4}$ ). With this system we quantitatively confirmed the reactions of $\mathrm{CH}_{3}{ }^{\circ}$ radicals in the porous materials and established that no coupling products $\left(\mathrm{C}_{2} \mathrm{H}_{6}\right.$ or $\left.\mathrm{C}_{2} \mathrm{H}_{4}\right)$ were formed. By contrast, when $\mathrm{CH}_{3}$. radicals reacted over $\mathrm{CeO}_{2}, \mathrm{CO}_{2}$ was produced as the major product. It should be noted that the reactions in the high surface area materials were carried out at only $200{ }^{\circ} \mathrm{C}$, while the 
reaction over $\mathrm{CeO}_{2}$ was carried out at $650^{\circ} \mathrm{C}$. It is possible that the reaction of $\mathrm{CH}_{3}{ }^{\circ}$ radicals in the high surface area materials occurs via electron transfer to defect sites, with the formation of methoxide ions $\left(\mathrm{CH}_{3} \mathrm{O}^{-}\right)$, but at the present there is no direct evidence for such a reaction.

\section{CATALYTIC CONVERSION OF $\mathrm{CH}_{3} \cdot$ RADICALS TO $\mathrm{CH}_{3} \mathrm{OH}$ AND HCHO}

The direct oxidation of methane to methanol and formaldehyde has been achieved over silica-supported molybdena and vanadia catalysts, although high selectivities to the desired oxygenates occur only at small $(<2 \%)$ methane conversion levels. Unless excess water is present, the production of formaldehyde greatly exceeds that of methanol. Liu et al. (4) proposed that the mechanism involves the formation of $\mathrm{CH}_{3} \cdot$ radicals, which react with the surface to yield methoxide ions. These ions may either decompose to $\mathrm{HCHO}$ and surface $\dot{\mathrm{O}} \mathrm{H}^{-}$ions, or they may react with $\mathrm{H}_{2} \mathrm{O}$ to produce $\mathrm{CH}_{3} \mathrm{OH}$. It was demonstrated that $\mathrm{MoO}\left(\mathrm{OCH}_{3}\right)_{4}$ reacts with water to yield $\mathrm{CH}_{3} \mathrm{OH}$ (4).

In order to more fully understand the role of surface methoxide ions in the formation of methanol and formaldehyde, methyl radicals, derived from the decomposition of azomethane, were allowed to react with pure $\mathrm{MoO}_{3}$ and with a $\mathrm{MoO}_{3} / \mathrm{SiO}_{2}$ catalyst. During the continuous flow of gases over the catalysts at a total pressure of about $35 \mathrm{mTorr}$, the dominant reaction was the coupling of $\mathrm{CH}_{3}$. radicals to form $\mathrm{C}_{2} \mathrm{H}_{6}$, but significant amounts of $\mathrm{HCHO}$ and $\mathrm{CH}_{3} \mathrm{OH}$ were also observed. The addition of $\mathrm{H}_{2} \mathrm{O}$ to the reactants enhanced the formation of $\mathrm{CH}_{3} \mathrm{OH}$ at $300^{\circ} \mathrm{C}$, but at $500^{\circ} \mathrm{C} \mathrm{HCHO}$ was the main oxygenate.

For temperature-programmed reaction (TPR) studies, $\mathrm{CH}_{3} \cdot$ radicals were first allowed to react with $\mathrm{MoO}_{3} / \mathrm{SiO}_{2}$ at $150^{\circ} \mathrm{C}$. Subsequently, as the temperature was increased $\mathrm{CH}_{3} \mathrm{OH}$ began to appear in the gas phase at about $170^{\circ} \mathrm{C}$ and was the main product up to $400^{\circ} \mathrm{C}$. In a separate experiment, after the $\mathrm{CH}_{3}$. radicals had reacted at $150^{\circ} \mathrm{C}, \mathrm{H}_{2} \mathrm{O}$ was 
adsorbed at 50. As shown in Fig. 2a, the appearance of $\mathrm{CH}_{3} \mathrm{OH}$ was shifted from $170{ }^{\circ} \mathrm{C}$ to $100^{\circ} \mathrm{C}$, presumably due to the reaction of water with surface methoxide ions. The role of water is further demonstrated in Fig. 2b, which illustrates the results obtained when the TPR experiment was carried out with the catalyst being continuously exposed to $28 \mathrm{mTorr}$ of $\mathrm{H}_{2} \mathrm{O}$. In this case, an appreciable amount of $\mathrm{CH}_{3} \mathrm{OH}$ was produced even at $80^{\circ} \mathrm{C}$, and the total amount of $\mathrm{CH}_{3} \mathrm{OH}$ formed over the temperature range from $80^{\circ}$ to $500^{\circ} \mathrm{C}$ was much greater than in the previous experiment. The $\mathrm{CH}_{3} \mathrm{OH}$ selectivity was quite good in the $100^{\circ}-200^{\circ} \mathrm{C}$ temperature range, which suggests that if $\mathrm{CH}_{3} \cdot$ radical could somehow be formed from $\mathrm{CH}_{4}$ under mild conditions, the high selectivity to $\mathrm{CH}_{3} \mathrm{OH}$ could be achieved.

\section{IDENTIFICATION OF SURFACE-GENERATED BENZYL RADICALS}

In addition to the coupling of two $\mathrm{CH}_{3}$. radicals to form $\mathrm{C}_{2} \mathrm{H}_{6}$, it also is possible to achieve cross coupling between $\mathrm{CH}_{3} \cdot$ radicals and other hydrocarbon radicals. The most notable example of cross coupling involves the coupling of methyl and benzyl radicals $\left(\mathrm{C}_{6} \mathrm{H}_{5} \mathrm{CH}_{2}{ }^{\circ}\right)$ to form ethylbenzene. While in the catalyst bed, a portion of the ethylbenzene is converted to the desired product, styrene. In general, catalysts that are effective for the oxidative coupling of $\mathrm{CH}_{4}$ also are effective for this cross coupling reaction; an exception being $\mathrm{Sm}_{2} \mathrm{O}_{3}$, which is a nonselective cross coupling catalyst.

Although most investigators agree that radicals are involved in the cross coupling reaction, it is not certain whether the reaction occurs on the surface or in the gas phase. Using the MIESR system, we have identified for the first time gas phase benzyl radicals that were formed when toluene and nitrous oxide reacted over a $\mathrm{Li} / \mathrm{MgO}$ catalyst. The experimental and a simulated spectrum are compared in Fig. 3. Nitrous oxide was used as the oxidant rather than molecular oxygen, to minimize the formation of benzyl peroxy radicals. In view of the nonselective reaction over $\mathrm{Sm}_{2} \mathrm{O}_{3}$ reacted over this catalyst, it is 


\section{$\because$}

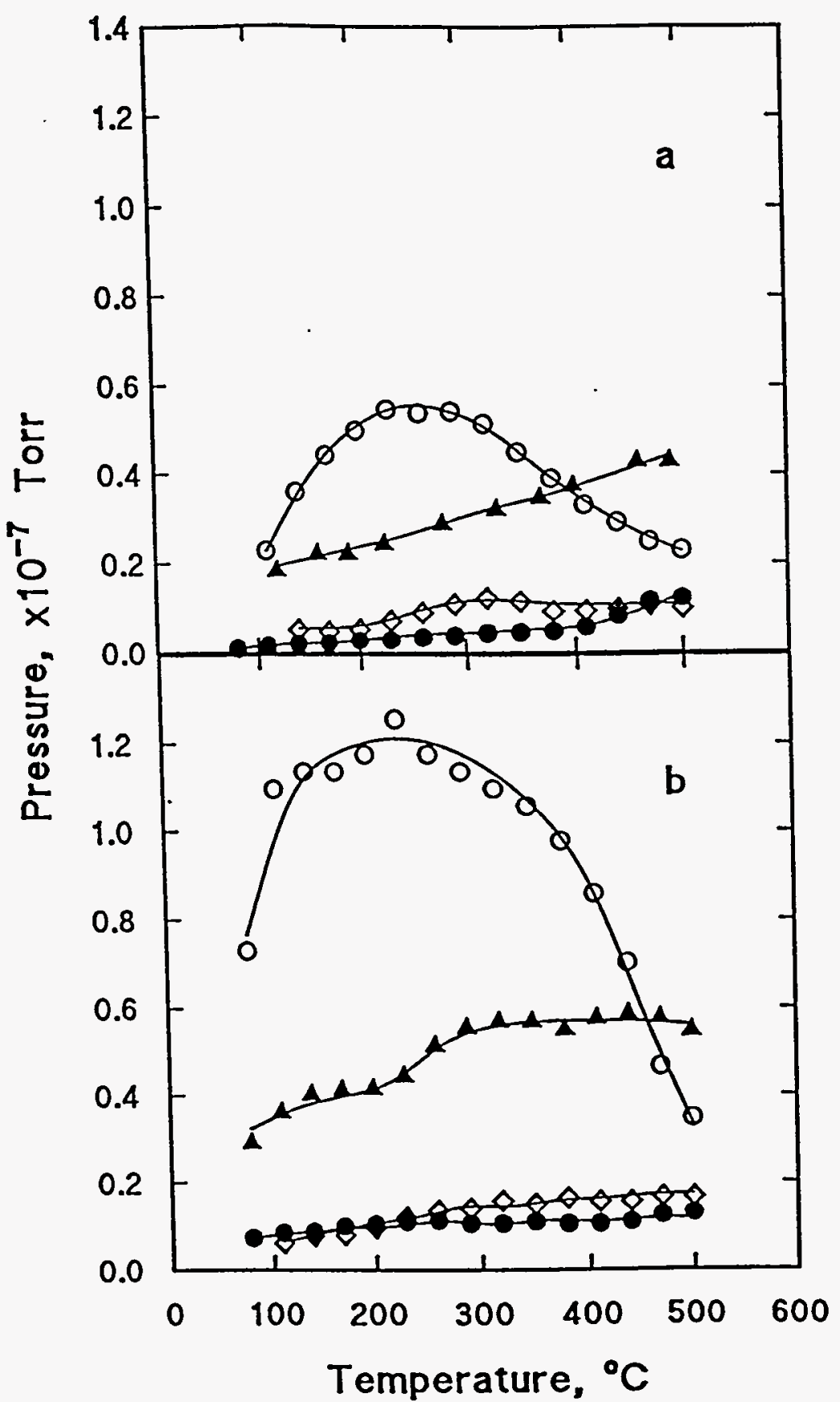

Fig. 2.

TPR results after reaction of 3 mTorr $\mathrm{CH}_{3} \cdot$ with $\mathrm{MoO}_{3} / \mathrm{SiO}_{2}$ for 30 min at $150^{\circ} \mathrm{C}$, followed by (a) adsorption of 30 mTorr $\mathrm{H}_{2} \mathrm{O}$ for 20 min at $50^{\circ} \mathrm{C}$ and (b) heating the sample in a flow of $28 \mathrm{mTorr} \mathrm{H}_{2} \mathrm{O}$ : $\mathrm{O}, \mathrm{CH}_{3} \mathrm{OH} ; \mathrm{A}, \mathrm{HCHO} ; \diamond, \mathrm{CO} ; \bullet, \mathrm{CO}_{2}$. 
significant that mainly $\mathrm{CH}_{3} \cdot$ radicals were produced when toluene and oxygen reacted over this catalyst (Fig. 3c). Apparently, $\mathrm{Sm}_{2} \mathrm{O}_{3}$ promotes the breaking of the $\mathrm{C}-\mathrm{C}$ bond, rather than the abstraction of hydrogen from the methyl group.

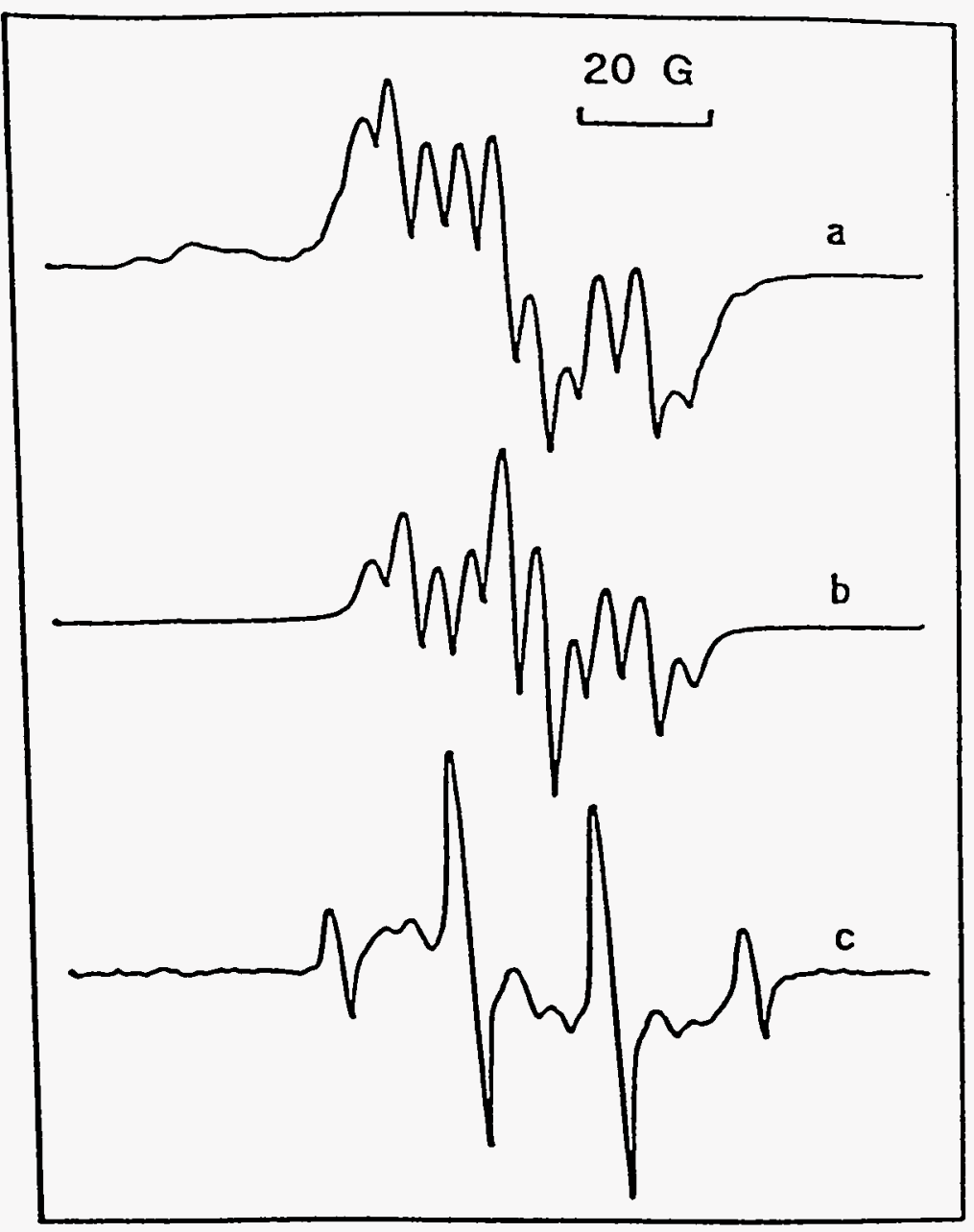

Fig. 3. EPR spectra of gas-phase radicals produced over catalysts: (a) experimental spectrum of benzyl radicals formed from toluene over a $\mathrm{Li}^{+} / \mathrm{MgO}$ catalyst; (b) simulated spectrum of benzyl radicals; (c) experimental spectrum of mainly methyl radicals formed from toluene over a $\mathrm{Sm}_{2} \mathrm{O}_{3}$ catalyst. Results were obtained with the catalysts at 650 ${ }^{\circ} \mathrm{C}$ in a flow of $\operatorname{Ar}(4.8 \mathrm{~mL} / \mathrm{min})$, toluene $(0.10 \mathrm{~mL} / \mathrm{min})$ and $\mathrm{N}_{2} \mathrm{O}$ $(0.10 \mathrm{~mL} / \mathrm{min}), \mathrm{P}_{\text {total }}=0.9$ Torr. 


\section{FORMATION OF OH· RADICALS UNDER RATE LIMITING CONDITIONS}

Surface-generated gas-phase $\mathrm{OH}$. radicals were previously detected by laser-induced fluorescence spectroscopy (LIF) over $\mathrm{La}_{2} \mathrm{O}_{3}$ and other basic lanthanide sesquioxide catalysts (5). The radicals were observed when $\mathrm{CH}_{4}$ and $\mathrm{O}_{2}$ reacted over the catalyst, but the actual reaction involved only $\mathrm{H}_{2} \mathrm{O}$ and $\mathrm{O}_{2}$, with $\mathrm{CH}_{4}$ being a source of $\mathrm{H}_{2} \mathrm{O}$. In the original work the conditions were chosen such that the reaction

$$
\frac{1}{2} \mathrm{H}_{2} \mathrm{O}+\frac{1}{4} \mathrm{O}_{2}=\mathrm{OH}
$$

was at equilibrium.

Subsequent research has been devoted to conditions such that the production of $\mathrm{OH} \cdot$ radicals is determined by a rate process, rather than by equilibrium. This was achieved, in part, by decreasing the amount of catalyst. When the amount of $\mathrm{La}_{2} \mathrm{O}_{3}$ catalyst was decreased from $7 \mathrm{mg}$ to less than $2 \mathrm{mg}$ at a reaction temperature of about $1000^{\circ} \mathrm{C}$, the activation energy and the orders of reaction were clearly different from those obtained at equilibrium. At total pressures $<50 \mathrm{~m}$ Torr the reaction orders became 0.47 with respect to $\mathrm{O}_{2}$ and 1.02 with respect to $\mathrm{H}_{2} \mathrm{O}$. The nearly half order is consistent with a mechanism in which $\mathrm{O}_{2}$ is dissociated in an equilibrium reaction, perhaps as

$$
\frac{1}{2} O_{2 g}+O_{s}^{2-}+2 O_{s}^{-}
$$

where $\square$ denotes an oxide ion vacancy. Then $\mathrm{OH}$. radicals are formed via the rate determining reaction

$$
\mathrm{H}_{2} \mathrm{O}_{8}+\mathrm{O}_{s}^{-} \rightarrow \mathrm{OH}_{8}+\mathrm{OH}_{s}^{-}
$$

which results in the first order reaction with respect to $\mathrm{H}_{2} \mathrm{O}$.

At total pressures greater than $150 \mathrm{mTorr}$ the production of $\mathrm{OH} \cdot$ radicals was found to be zero order with respect to $\mathrm{O}_{2}$ and $\mathrm{H}_{2} \mathrm{O}$, as shown in Fig. 4, both with small and large amounts of 


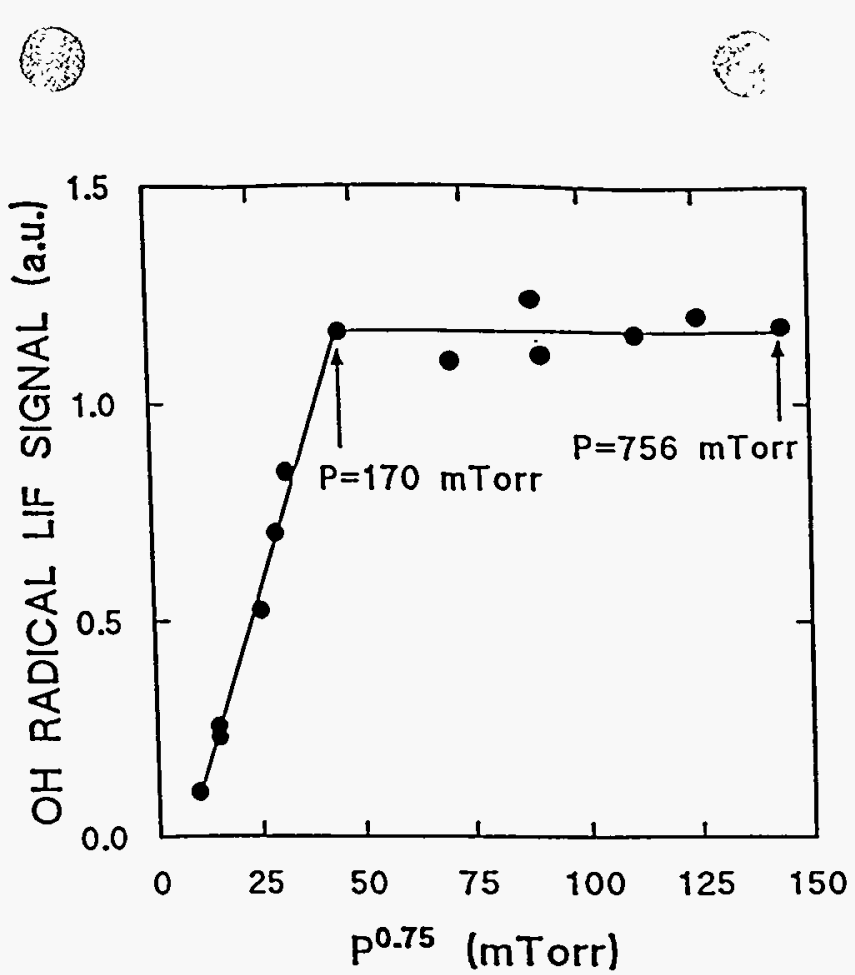

Fig. 4. The effect of total water and oxygen partial pressure at a fixed ratio of 1.2:1 water-to-oxygen on hydroxyl radical production over $\mathrm{La}_{2} \mathrm{O}_{3}$ at $1223 \mathrm{~K}$.

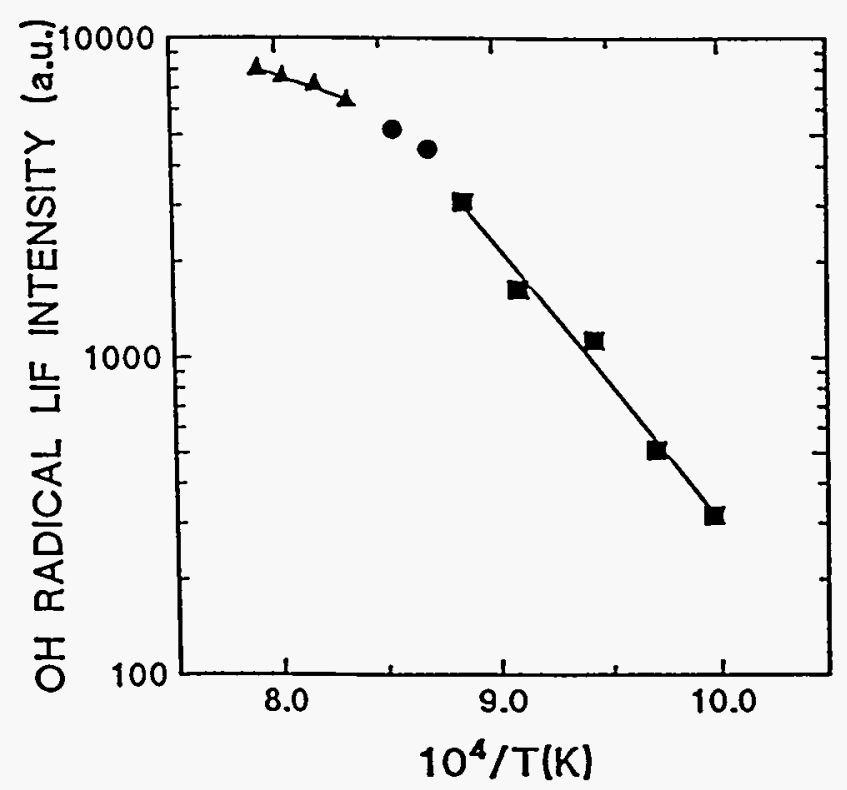

Fig. 5. Arrhenius plot of OH· radicals over $\mathrm{La}_{2} \mathrm{O}_{3}$ with $170 \mathrm{mTorr} \mathrm{H}_{2} \mathrm{O}$ and $136 \mathrm{mTorr} \mathrm{O}_{2}$. The apparent activation energy was $41 \mathrm{kcal} / \mathrm{mol}$ for temperatures less than $1173 \mathrm{~K}(\mathbb{m})$, and about $10 \mathrm{kcal} / \mathrm{mol}$ at temperatures over $1223 \mathrm{~K}(\mathbf{\Lambda})$. 
catalyst. Higher reaction temperatures also favor the zero order kinetics. These results suggest a change in the rate limiting step, which is supported by a change in the apparent activation. energy. This change in activation energy is evident in the results of Fig. 5 . Photophysical effects, such as quenching of the $\mathrm{OH} \cdot$ fluorescence clearly did not give rise to the effect. At the pressures of these experiments it seems that gas phase diffusion would not be rate limiting. The most reasonable explanation for the zero order kinetics is related to oxide ion diffusion, which, in effect, would limit the formation of $O$ centers.

Even though the reaction becomes zero order at rather low partial pressures of $\mathrm{O}_{2}$ and $\mathrm{H}_{2} \mathrm{O}$, the concentrations of $\mathrm{OH} \cdot$ radicals are comparable to those that might be expected during $\mathrm{CH}_{4}$ oxidation at atmospheric pressures. Thus, a catalyst such as $\mathrm{La}_{2} \mathrm{O}_{3}$ could contribute to catalytic combustion via the generation of $\mathrm{OH}$ - radicals. The production of $\mathrm{OH} \cdot$ radicals was also investigated over other catalysts including $\mathrm{Nd}_{2} \mathrm{O}_{3}, \mathrm{Sm}_{2} \mathrm{O}_{3}, \mathrm{Yb}_{2} \mathrm{O}_{3}$ and . $\mathrm{CeO}_{2}$. The order of activity for the oxides was $\mathrm{La}_{2} \mathrm{O}_{3}>\mathrm{Nd}_{2} \mathrm{O}_{3}>\mathrm{Sm}_{2} \mathrm{O}_{3}>\mathrm{Yb}_{2} \mathrm{O}_{3}>$ $\mathrm{CeO}_{2}$. No radicals were detected over $\mathrm{CeO}_{2}$. The order of reactivity is the same as that which was previously observed in the production of $\mathrm{CH}_{3}$. radicals during the reaction of $\mathrm{CH}_{4}$ and $\mathrm{O}_{2}$ over these oxides. This parallel behavior suggests that both the mechanism and the nature of the active centers are similar. That is, the same reactive form of surface oxygen is responsible for the abstraction of hydrogen atoms from both $\mathrm{CH}_{4}$ and $\mathrm{H}_{2} \mathrm{O}$ to give the corresponding radicals.

\section{REFERENCES}

1. Tong, Y.; Lunsford, J. H. J. Am. Chem. Soc. 1991, 113, 4741.

2. Yamamoto, H.; Chu, H. Y.; Xu, M.; Shi, C.; Lunsford, J. H. J. Catal. 1993, 142, 325.

3. Wang, D.; Xu, M.; Shi, C.; Lunsford, J. H. Catal. Lett. 1993, 18, 323. 


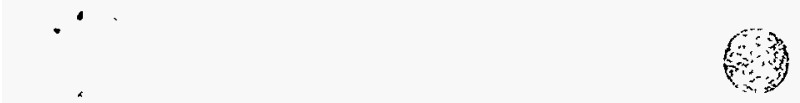

4. Liu, H.-F.; Liu, R.-S.; Liew, K. Y.; Johnson, R. E.; Lunsford, J. H. J. Am. Chem. Soc. $1984,106,4117$.

5. Anderson, L. C.; Xu, M.; Mooney, C. E.; Rosynek, M. P.; Lunsford, J. H. J. Am. Chem. Soc. 1993, 115, 6322.

\section{PAPERS SUBMITTED OR PUBLISHED}

1. "Conversion of Methyl Radicals to Methanol and Formaldehyde over Molybdenum Oxide Catalysts," Pak, S.; Rosynek, M. P.; Lunsford, J. H., submitted to J. Phys. Chem. 